\title{
Air Pollution and Stroke
}

\author{
Kuan Ken Lee, Mark R. Miller, Anoop S. V. Shah
}

BHF Centre for Cardiovascular Science, University of Edinburgh, Edinburgh, UK

The adverse health effects of air pollution have long been recognised; however, there is less awareness that the majority of the morbidity and mortality caused by air pollution is due to its effects on the cardiovascular system. Evidence from epidemiological studies have demonstrated a strong association between air pollution and cardiovascular diseases including stroke. Although the relative risk is small at an individual level, the ubiquitous nature of exposure to air pollution means that the absolute risk at a population level is on a par with "traditional" risk factors for cardiovascular disease. Of particular concern are findings that the strength of this association is stronger in low and middle income countries where air pollution is projected to rise as a result of rapid industrialisation. The underlying biological mechanisms through which air pollutants exert their effect on the vasculature are still an area of intense discussion. A greater understanding of the effect size and mechanisms is necessary to develop effective strategies at individual and policy levels to mitigate the adverse cardiovascular effects of air pollution.
Correspondence: Anoop S. V. Shah BHF Centre for Cardiovascular Science, University of Edinburgh, SU.305

Chancellor's Building, Edinburgh EH16 4SB, UK

Tel: +44-131-242-6432

Fax: +44-131-242-6379

E-mail:Anoop.Shah@ed.ac.uk

Received: December 13, 2017

Revised: January 18, 2018

Accepted: January 19, 2018

Keywords Air pollution; Stroke; Cardiovascular diseases; Public health

\section{Introduction}

Exposure to air pollution is now increasingly recognised as a major public health issue and is one of the leading causes of mortality and morbidity, contributing to 6.5 million deaths and 167.3 million disability-adjusted life years (DALYs; a measure of time spent in ill health, disability or premature death) in 2015. ${ }^{1}$ More importantly it ranks within the top five risk factors for mortality in emerging economies such as India and China (Figure 1). ${ }^{1}$ It was estimated that $99 \%$ of deaths attributed to household air pollution and $89 \%$ of deaths attributed to ambient air pollution occurred in low and medium income countries (LMICs). ${ }^{2}$

Although exacerbation of respiratory conditions is intuitively linked with air pollution, over the last two decades evidence has emerged linking air pollution and cardiovascular mortality and morbidity. ${ }^{3.4}$ Recently both epidemiological and mechanistic studies have shown robust associations between air pollu- tion and atherosclerotic cardiovascular diseases, including myocardial infarction ${ }^{3}$ and stroke. ${ }^{5}$ The Global Burden of Diseases study estimated that in 2015, air pollution accounted for $19 \%$ of all cardiovascular death, $21 \%$ of deaths due to stroke and $24 \%$ deaths due to ischaemic heart disease. ${ }^{6}$

Stroke remains one of the leading causes of morbidity and mortality worldwide, accounting for over 118.6 million DALYS and 6.3 million deaths in $2015 .^{7}$ It is important to note that this burden of disease varies significantly across different parts of the world. Over the past 20 years, high income countries have experienced a significant decline in age-standardized mortality and DALY rates of approximately 20\% to $40 \% .^{7.8}$ Conversely, the vast majority of strokes (approximately 85\%) now occur in LMICs where incidence, deaths and DALYs have increased significantly over this period. ${ }^{7}$ It is also in LMICs where air pollution is projected to increase significantly over the next few decades due to rapid industrialisation. ${ }^{9,10}$ 


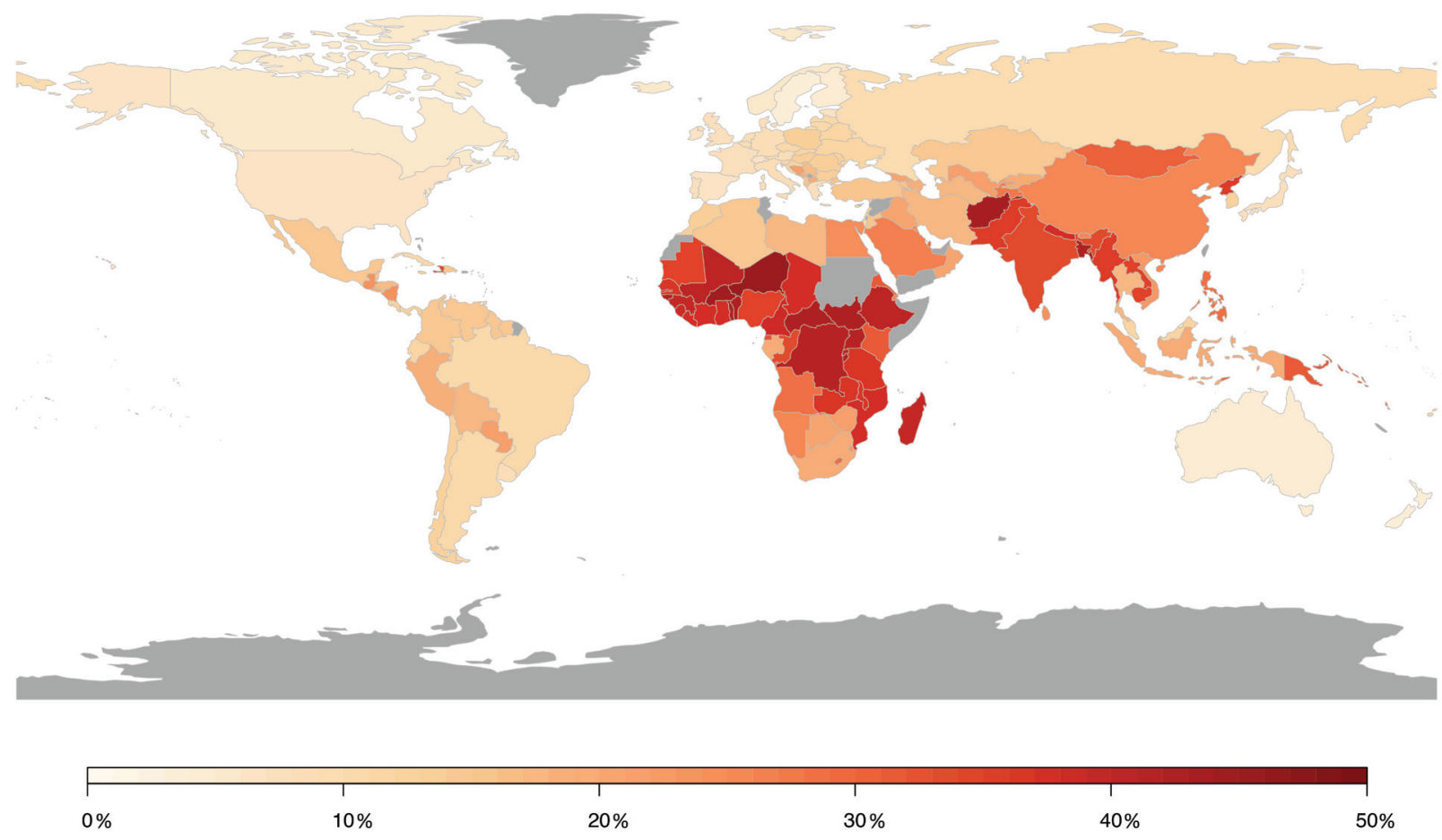

Figure 1. Population attributable risk of cerebrovascular disease associated with air pollution worldwide. Estimates from Institute for Health Metrics and Evaluation (IHME).

In this review, we describe the epidemiological evidence for the association between air pollution and stroke, and the proposed pathophysiological pathways linking air pollutants to atherothrombosis that underlies a significant proportion of cerebrovascular disease.

\section{What is air pollution?}

Air pollution is an expansive term consisting of a complex mixture of thousands of components from a wide range of different sources. The main pollutants currently recognised to pose risk to health include airborne particulate matter (PM) and gaseous pollutants such as ozone $\left(\mathrm{O}_{3}\right)$, sulphur dioxide $\left(\mathrm{SO}_{2}\right)$, carbon monoxide (CO), and nitrogen oxides including nitrogen dioxide $\left(\mathrm{NO}_{2}\right)$ and nitrogen oxide $\left(\mathrm{NO}_{x}\right)$.

\section{Particulate matter}

Airborne PM is classified by the size of the particles into coarse particles or $\mathrm{PM}_{10}$ (diameter of $10 \mu \mathrm{m}$ or less), fine particles or $\mathrm{PM}_{2.5}$ (diameter of $2.5 \mu \mathrm{m}$ or less) and ultrafine particles or nanoparticles (diameter smaller than $0.1 \mu \mathrm{m}$ ). The size and composition of particles primarily depend on its source. Airborne $\mathrm{PM}_{10}$ is chiefly a result of resuspension of soil, road dust by wind and moving vehicles, construction work and industrial emissions. $\mathrm{PM}_{2.5}$ is mainly derived from the combustion of fossil fuel, including motorized road traffic, power plants, industrial and residential heating using oil, coal, or wood. Particles formed in this way are commonly composed of carbon, transitional metals, complex organic molecules, sulphate, and nitrates. Vehicle engine exhaust (especially diesel exhaust) is particularly rich in nanoparticles, which, while contributing only a very small fraction of the total mass of $\mathrm{PM}_{2.5}$, have a greater reactive surface area for a given mass.

\section{Gaseous pollution}

The gaseous pollutants predominantly consist of $\mathrm{SO}_{2}, \mathrm{NO}_{x_{1}} \mathrm{CO}$, and $\mathrm{O}_{3} . \mathrm{SO}_{2}$ is mainly produced in fossil fuel power plants, whilst $\mathrm{NO}_{x}$ mainly originates from motorised road traffic, residential heating, power generation and industrial sources. Besides their own inherent toxicity, $\mathrm{SO}_{2}$ and $\mathrm{NO}_{x}$ can contribute in atmospheric photochemical reactions resulting in complex secondary particles composed of inorganic and organic compounds. Ground level $\mathrm{O}_{3}$ is a form of secondary gaseous pollutant made as a result of photochemical reactions of $\mathrm{NO}_{2}$ with volatile hydrocarbons in the presence of sunlight and is a major constituent of photochemical smog. 


\section{Global variation in air pollution concentrations}

In LMICs, biomass fuel, agriculture related burning, open fires and forest burning are more prevalent. In rural communities, as well as deprived populations in urban regions, exposure to household air pollution is intimately linked with poverty. This is primarily due to the dependence on biomass fuel, firewood and charcoal as a means for cooking and heating with traditional stoves. For example in sub-Saharan Africa and most of South Asia, firewood remains the main source of fuel. ${ }^{11}$ The nature of air pollution is expected to change significantly as LMICs industrialise and reliance on biomass fuel decreases. ${ }^{12}$ Over the past few decades, household air pollution associated with poverty and traditional lifestyles has decreased worldwide but remains an important risk factor. ${ }^{13}$ On the contrary ambient air pollution is increasing significantly in LMICs as these regions become more industrialized. ${ }^{14}$

Air pollutant levels have substantial temporal and spatial variation. Temporal variation of daily average air pollutant concentrations is often related to weather conditions affecting the dispersion of pollutants. These include wind direction, speed, and atmospheric stability. Temperature and sunlight are crucial in the formation of $\mathrm{O}_{3}$; therefore, concentrations are typically highest during the warmest, high-intensity sunlight hours of the day. Consequently, $\mathrm{O}_{3}$ levels peak between noon and 9:00 PM during the time when individuals are outdoors, resulting in significant human exposure. Traffic-related pollution such as soot, ultrafine particles and combustion-derived gaseous pollutants often peak during the morning and evening rush hours, resulting in high exposure for people commuting to work.

Spatial variation is related to local and regional sources. For example, $\mathrm{PM}_{2.5}$ concentration has been found to be significantly higher in traffic sites compared to urban background sites. ${ }^{15}$ $\mathrm{PM}_{2.5}$ can travel large distances (>100 km) resulting in high background concentrations over wide areas. In West Africa, satellite data indicate that wind-blown dust from the Sahara Desert causes increased $\mathrm{PM}_{2.5}$ air pollution that is believed to result in a significant burden of disease in one of the most densely populated regions in Africa and beyond..$^{16}$

\section{Air pollution and stroke: epidemiological evidence}

Patients with cardiovascular disease share many risk factors such as obesity, hyperlipidaemia, hypertension, smoking, poor diet, and inactive lifestyle. Crucially, air pollution differs from other modifiable risk factors because exposure to air pollution, for the large majority of people, is unavoidable. Therefore, even though the individual risk estimates for exposure to air pollu- tion are relatively small compared to the other cardiovascular risk factors, since exposure to (some form of) air pollution is ubiquitous, the overall population attributable risk and subsequent burden is significant. ${ }^{17}$

\section{Long-term exposure}

Most studies of long-term exposure use air pollution levels at residential addresses over months to years as a proxy for longterm accumulated individual exposure. Individual exposure is estimated using residential distance to major roadways, measurements from nearby fixed air quality monitoring stations or advanced modelling using land-use databases, meteorological data, traffic density, and emissions database. The majority of studies looking at the long-term effects of air pollution on cardiovascular disease have been on $\mathrm{PM}_{2.5}$. A 2013 meta-analysis reported that $\mathrm{PM}_{2.5}$ was associated with a pooled excess risk of $6 \%$ (95\% confidence interval [Cl], 4\% to $8 \%$ ) for all-cause mortality and $11 \%(95 \% \mathrm{Cl}, 5 \%$ to $16 \%)$ for cardiovascular mortality ${ }^{18}$ for every $10 \mu \mathrm{g} / \mathrm{m}^{3}$ increment. Similar associations have been found for certain gaseous co-pollutants, with a 2014 meta-analysis reported a $13 \%(95 \% \mathrm{Cl}, 9 \%$ to $18 \%)$ increase in cardiovascular mortality per $10 \mu \mathrm{g} / \mathrm{m}^{3}$ increase in $\mathrm{NO}_{2}$ concentration. ${ }^{19}$ We summarize several key longitudinal studies in Table $1 .{ }^{20-25}$ Associations with cerebrovascular disease was found to be stronger in LMICs where air pollutant levels were greater. ${ }^{20}$ Interestingly, increased risk was also observed in regions where $\mathrm{PM}_{2.5}$ met European Union air quality standard of $25 \mu \mathrm{g} / \mathrm{m}^{3.21}$ Carotid artery stenosis, a known precursor to ischaemic strokes, was recently reported to be independently associated with $\mathrm{PM}_{2.5}$ concentration even after adjusting for known cardiovascular risk factors. ${ }^{26}$

\section{Short-term exposure}

In the early 1980s, a study in England and Wales investigating the association between fluctuations in meteorological variables and cerebrovascular mortality found an unexpectedly strong correlation with atmospheric particulate air pollution levels. ${ }^{27}$ Several years later, a study in China found indoor coal fumes to be a risk factor for stroke, independent of age, blood pressure, and cigarette smoking. ${ }^{28}$ In the United States, a study published in 1994 reported a weak but significant association between daily PM pollution and cerebrovascular mortality (relative risk of 1.15) using cause of death data between 1973 and $1980 .{ }^{29}$ Since then, there has been a large number of ecological studies investigating the short-term effects of air pollution (>100)..$^{5}$ Of note, Dominici et al. ${ }^{30}$ reported a $0.81 \%(95 \% \mathrm{Cl}$, $0.30 \%$ to $1.32 \%$ ) increase in hospital admission due to cerebrovascular disease per $10 \mu \mathrm{g} / \mathrm{m}^{3}$ increment in same-day $\mathrm{PM}_{2.5}$ 
Table 1. Selected studies of the association between long-term exposure to air pollution and cerebrovascular disease

\begin{tabular}{|c|c|c|c|}
\hline Location of study, author & Study design & Exposure measurement & Significant findings \\
\hline $\begin{array}{l}\text { USA ( } 36 \text { cities) } \\
\text { Miller et al. }(2007)^{22}\end{array}$ & $\begin{array}{l}65,893 \text { Postmenopausal women } \\
\text { Median follow-up of } 6 \text { years }\end{array}$ & $\begin{array}{l}\text { Per } 10 \mu \mathrm{g} / \mathrm{m}^{3} \text { increase } \\
\text { in mean } \mathrm{PM}_{2.5} \\
\text { concentration }\end{array}$ & $\begin{array}{l}\text { Stroke incidence increased by } 35 \% \\
(95 \% \mathrm{Cl}, 8 \%-68 \%) \\
\text { Stroke deaths increased by } 83 \% \\
(95 \% \mathrm{Cl}, 11 \%-200 \%)\end{array}$ \\
\hline $\begin{array}{l}\text { California, USA } \\
\text { Lipsett et al. }(2011)^{23}\end{array}$ & $\begin{array}{l}\text { 124,614 Current and former public school professionals } \\
\text { Median follow-up of } 5.6 \text { years }\end{array}$ & $\begin{array}{l}\text { Per } 10 \mu \mathrm{g} / \mathrm{m}^{3} \text { increase } \\
\text { in } \mathrm{PM}_{2.5}\end{array}$ & $\begin{array}{l}\text { Stroke incidence increased by } 19 \% \\
(95 \% \mathrm{Cl}, 2 \%-38 \%)\end{array}$ \\
\hline $\begin{array}{l}\text { England, UK } \\
\text { Atkinson et al. }(2013)^{24}\end{array}$ & $\begin{array}{l}\text { 836,557 Patients registered with } 205 \text { English general practices } \\
\text { Median follow-up of } 5 \text { years }\end{array}$ & $\begin{array}{l}\text { Per interquartile } \\
\text { change in } \mathrm{SO}_{2} \\
\left(2.2 \mu \mathrm{g} / \mathrm{m}^{3}\right)\end{array}$ & $\begin{array}{l}\text { Stroke incidence increased by } 4 \% \\
(95 \% \mathrm{Cl}, 2 \%-6 \%)\end{array}$ \\
\hline $\begin{array}{l}\text { New-England region, USA } \\
\text { Kloog et al. }(2012)^{25}\end{array}$ & $\begin{array}{l}24,066 \text { Hospital admissions of medicare recipients aged } 65 \text { years } \\
\text { or older between years } 2000-2006\end{array}$ & $\begin{array}{l}\text { Per } 10 \mu \mathrm{g} / \mathrm{m}^{3} \text { increase } \\
\text { in } \mathrm{PM}_{2.5}\end{array}$ & $\begin{array}{l}\text { Stroke hospitalisation increased by } \\
3.49 \%(95 \% \mathrm{Cl}, 0.09 \%-5.18 \%)\end{array}$ \\
\hline $\begin{array}{l}\text { Shenyang, China } \\
\text { Zhang et al. }(2011)^{20}\end{array}$ & 9,941 Residents followed up from 1998-2009 & $\begin{array}{l}\text { Per } 10 \mu \mathrm{g} / \mathrm{m}^{3} \text { increase } \\
\text { in } \mathrm{PM}_{10} \text { and } \mathrm{NO}_{2}\end{array}$ & $\begin{array}{l}\text { Stroke mortality increased by } 49 \% \\
(95 \% \mathrm{Cl}, 45 \%-53 \%) \text { for } \mathrm{PM}_{10} \text { and } \\
144 \%(95 \% \mathrm{Cl}, 127 \%-162 \%) \text { for } \\
\mathrm{NO}_{2}\end{array}$ \\
\hline $\begin{array}{l}\text { Europe (multiple countries) } \\
\text { Stafoggia et al. (2014) }\end{array}$ & $\begin{array}{l}\text { 99,446 People enrolled across } 11 \text { cohorts from 1997-2007 } \\
\text { Mean follow-up of } 11.5 \text { years }\end{array}$ & $\begin{array}{l}\text { Per } 5 \mu \mathrm{g} / \mathrm{m}^{3} \text { increase } \\
\text { in } \mathrm{PM}_{2.5}\end{array}$ & $\begin{array}{l}\text { Overall stroke incidence increased by } \\
19 \%(95 \% \mathrm{Cl},-12 \% \text { to } 62 \%) \text {. In- } \\
\text { creased risk was observed even at } \\
\text { concentrations that met the Europe- } \\
\text { an Union standard of } 25 \mu \mathrm{g} / \mathrm{m}^{3} \text { (33\% } \\
\text { increase }[95 \% \mathrm{Cl}, 1 \%-77 \%])\end{array}$ \\
\hline
\end{tabular}

$\mathrm{PM}_{2.5}$, particulate matter diameter of $2.5 \mu \mathrm{m}$ or less; $\mathrm{Cl}$, confidence interval; $\mathrm{SO}_{2}$, sulphur dioxide; $\mathrm{PM}_{10}$, particulate matter diameter of $10 \mu \mathrm{m}$ or less; $\mathrm{NO}_{2}$, nitrogen dioxide.

across 204 United States counties. In contrast, a study in Chile, where mean $\mathrm{PM}_{2.5}$ concentrations are over twice as high at 31 $\mu \mathrm{g} / \mathrm{m}^{3}$, hospitalisations for cerebrovascular disease increased by $1.29 \%\left(95 \% \mathrm{Cl}, 0.55 \%\right.$ to $2.03 \%$ ) for every $10 \mathrm{\mu g} / \mathrm{m}^{3}$ increment. ${ }^{31}$ In Edmonton, Canada, the association between $\mathrm{NO}_{2}$ and ischaemic stroke were found to be significantly stronger for individuals with a history of stroke, heart disease, and diabetes (odds ratio [OR], 2.31 [95\% Cl, 1.39 to 3.83]; OR, 1.99 [95\% Cl, 1.20 to 3.28]; and OR, 2.03 [95\% Cl, 1.14 to 3.59], respectively). ${ }^{32}$

A recent systematic review and meta-analysis reported that gaseous and PM air pollutants have a temporal association with hospital admissions and mortality due to stroke (Figure 2). ${ }^{5}$ Both $\mathrm{PM}_{2.5}$ and $\mathrm{PM}_{10}$ were associated with admission to hospital for stroke and mortality from stroke, with a stronger association with $\mathrm{PM}_{2.5}$ with a relative risk of $1.011(95 \% \mathrm{Cl}$, 1.011 to 1.012 ) per $10 \mathrm{\mu g} / \mathrm{m}^{3}$ increment. $\mathrm{NO}_{2}$ was the most studied pollutant with a $1.014(95 \% \mathrm{Cl}, 1.009$ to 1.019$)$ relative increase in hospital admission or mortality due to stroke per 10 parts per billion (ppb) increment. Both $\mathrm{SO}_{2}$ and $\mathrm{CO}$ were significantly associated with admission or mortality with relative risks of $1.019(95 \% \mathrm{Cl}, 1.011$ to 1.027$)$ per $10 \mathrm{ppb}$ increment and 1.015 (95\% Cl, 1.004 to 1.026) per 1 part per million (ppm) increment respectively. $\mathrm{O}_{3}$ only had a weak association with relative risk of $1.001(95 \% \mathrm{Cl}, 1.000$ to 1.002$)$ per $10 \mathrm{ppb}$ increment. The pooled analysis of over 6.2 million stroke events

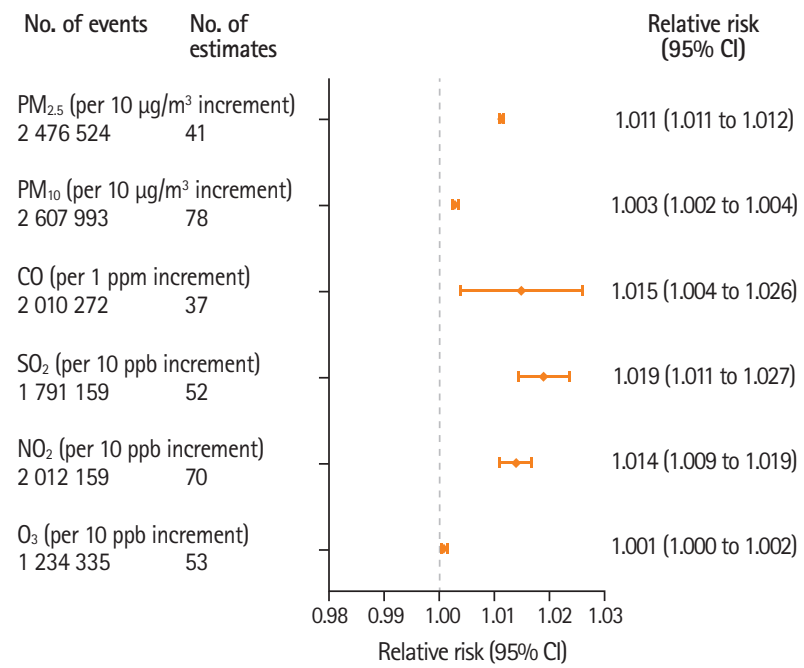

Figure 2. Association between air pollutants and hospitalisation or mortality from stroke. Adapted from Shah et al. ${ }^{5} \mathrm{Cl}$, confidence interval; $\mathrm{PM}_{2.5}$, particulate matter diameter of $2.5 \mu \mathrm{m}$ or less; $\mathrm{PM}_{10}$, particulate matter diameter of $10 \mu \mathrm{m}$ or less; $\mathrm{CO}$, carbon monoxide; ppm, part per million; $\mathrm{SO}_{2}$, sulphur dioxide; ppb, part per billion; $\mathrm{NO}_{2}$, nitrogen dioxide; $\mathrm{O}_{3}$, ozone.

across 28 countries worldwide, demonstrated that associations persists even after stratification by study design, age and hospitalisation or mortality outcome. Pooled estimates demonstrated stronger associations in LMICs than high income countries for $\mathrm{NO}_{2}$ (relative risks of 1.019 [95\% $\mathrm{Cl}, 1.011$ to 1.027 ] vs. $1.012\left[95 \% \mathrm{Cl}_{1} 1.006\right.$ to 1.017$\left.]\right)$ and $\mathrm{PM}_{10}(1.004$ [95\% Cl, 
1.002 to 1.006$]$ vs. 1.002 [95\% $\mathrm{Cl}, 1.001$ to 1.003$])$.

\section{Limitations of epidemiological studies}

Most epidemiological studies are performed in high income countries; however, it is in the LMICs where the effects of air pollution are most marked and the incidence of stroke is continuing to rise significantly. In most outdoor air pollution epidemiological studies, individual exposures are extrapolated from ambient air pollutant concentrations reported at a regional level or recorded by the nearest fixed air quality monitor. This approach assumes a uniform exposure across the area without precisely accounting for within-region variability or variations in personal exposure of the individual. Unlike other acute conditions, the time of onset may precede mortality due to stroke by days or weeks, leading to significant exposure misclassification. Furthermore, many studies did not adjust for 'traditional' risk factors for cardiovascular disease such as diabetes, hypertension, smoking, and socioeconomic deprivation which may confound the association between air pollution and stroke. Whilst the associations reported in epidemiological studies are significant, proving a causal relationship between the different air pollutants and stroke is more challenging. Experimental and clinical data are therefore crucial in establishing the biological plausibility of this relationship.

\section{Experimental evidence for the association between air pollution and stroke}

The potential for harm from air pollution is related to both exposure (e.g., the concentration, dose and period of exposure, and the ability of the body to clear the pollutants) and toxicity of the pollutant (e.g., reactivity of the material, ability access different biological compartments). In regards to the latter, for PM pollution, the smaller the particle, the greater the potential for harm due to ability to penetrate deeper into the lung and larger reactive surface area available (for a given mass and composition). Consequently, association between $\mathrm{PM}_{2.5}$ and cardiovascular disease has been more marked and consistent than $\mathrm{PM}_{10}$ in epidemiological studies. ${ }^{3,5}$ Smaller nanoparticles are able to penetrate the alveolar spaces of the lung and may even infiltrate the blood stream to reach systemic organs. ${ }^{33}$ The chemical composition of particles is another crucial factor in determining its biological effects once it has gained access into the human body. Combustion-derived particles have a vast cocktail of surface chemicals, including reactive transition metals and organic hydrocarbons, which are thought to be significant drivers of inflammation and oxidative stress. Although epidemiological studies have limitations in proving causality between air pollution exposure and cerebrovascular disease, several cellular, animal, controlled exposure, and longitudinal clinical studies have provided robust biologically plausible evidence underlying these associations. ${ }^{34}$

The biological mechanisms by which pollutants could promote stroke are complex, and remained to be fully elucidated. In more simplified in vitro studies using cultures of neurons, astrocytes, and microglia have demonstrated increased susceptibility to oxygen and glucose deprivation, ${ }_{1}^{35}$ alteration in synaptic function ${ }^{36}$ and upregulation in inflammatory cytokines ${ }^{37}$ when exposed to PM air pollutants. However, in vitro studies are frequently performed by directly exposing cells to very high concentrations of PM. Whether particles are able to translocate (pass from the lung into the blood) in sufficient concentration to cause these effects after inhalation in vivo is debatable, and other mechanistic pathways will undoubtedly play a role in the pathophysiology.

Several animal models have been used to investigate the effects of air pollution on stroke. Intra-tracheal instillation of combustion-derived PM in healthy versus stroke-prone spontaneously hypertensive rats showed increase in cardiac and pulmonary oxidative stress markers. ${ }^{38}$ Interleukin- 6 and other proinflammatory molecules released after diesel exhaust inhalation in mice are associated with platelet activation, increased fibrinogen, factor VIII, and tissue factor release. ${ }^{39}$ Exposure to vehicle exhaust was also demonstrated to alter blood-brain barrier function in apolipoprotein-E knockout mice. ${ }^{40}$ In China, rats treated with $\mathrm{PM}_{10}$ from a coal-burning city were reported to have changes consistent with cerebral ischaemia (i.e., endothelial dysfunction, inflammation, and neuro-functional impairment) on electron microscopic analysis of brain slices. ${ }^{35}$

Controlled exposure studies in human subjects have also provided important insight. In healthy adults, diesel exhaust exposure increased platelet activation and thrombus formation at damaged blood vessels ex vivo. ${ }^{41}$ In patients with coronary artery disease, it was demonstrated that endogenous fibrinolytic capacity is inhibited due to a reduction in acute tissue plasminogen activator release. ${ }^{42}$ Air pollution may also reduce endothelial function through increased endothelial cell apoptosis $^{43}$ and decreased circulating levels of endothelial progenitor cells. ${ }^{44}$ In a community of elderly community-dwelling individuals, $\mathrm{PM}_{2.5}$ was associated with higher resting cerebrovascular resistance and lower cerebral blood flow velocity using transcranial Doppler ultrasound measurements. ${ }^{45}$ 


\section{Mechanisms: inflammation, oxidative stress, and lipid modification}

Cellular, animal, and clinical studies have led to several hypotheses to explain the adverse cardiovascular effects of ambient PM. It is likely that the relative contribution of each pathway depends on the physicochemical property of the particular pollutant and individual susceptibility. ${ }^{46,47}$ The classical "inflammation" hypothesis is that particles inhaled into the lungs are ingested by macrophages, activating a local inflammatory response within the lung. Inflammatory mediators then "spillover" into the systemic circulation leading to "indirect" effects on the cardiovascular system. ${ }^{48}$ Exposure to urban PM has been shown to cause pulmonary inflammation and elevated circulating levels of leucocytes and inflammatory cytokines such as tumour necrosis factor alpha, interleukin-1, interleukin-6, and acute phase reactants such as C-reactive protein and fibrinogen. ${ }^{49-51}$ Inflammatory pathways also act in concert with oxidative stress, potentially amplifying the pathophysiological actions of pollutants. Generation of oxidative stress in the vascular endothelium will decrease the availability of NO, a key regulator of vascular tone and blood pressure. Exposure to diesel exhaust led to impaired endothelium-dependent mediated vasodilation and decreased endothelial NO bioavailability. ${ }^{52}$ Oxidative stress also leads to alteration in circulating lipids. Diesel exhaust particles have been shown to oxidise low-density lipoprotein generation and stimulate the release of other highly oxidised phospholipids. ${ }^{53}$ Ambient particles are associated with an increase in plasma lipoprotein-associated phospholipase A2, an independent risk factor for stroke..$^{54}$ These proatherogenic molecules diffuse into subendothelial cells and cause further endothelial dysfunction.

\section{Mechanisms: translocation of nanoparticles}

More recently, discovery of the nanoparticle fraction of airborne PM pollution led to the hypothesis that due to the small size of these nanoparticles, they are able to traverse the alveolar-capillary barrier to enter systemic circulation and directly affect the vasculature and circulating blood cells. ${ }^{55}$ In vitro studies have demonstrated that exposure to combustion-derived nanoparticles activate a proinflammatory response in endothelial cells. ${ }^{56}$ Combustion-derived nanoparticles were also found to upregulate the expression of adhesion molecules, intercellular adhesion molecule-1, and vascular cell adhesion protein-1 on the surface of endothelial cells..$^{57,58}$ This is a crucial step during the initiating events of atherosclerosis which result in the retention of macrophages and monocytes in the subendothelial space. Diesel exhaust particles have been shown to increase endothelial cell permeability through downregulation of tight junction proteins, increased transendothelial resistance and redistribution of vascular endothelial cadherin from cell membrane intracellularly. ${ }^{59-61}$ There is also evidence that particles may translocate to central regions at the level of the nasal passage, in particular the olfactory bulb where high doses of particles deposit due to route of air-flow. The particles could then penetrate the nasal respiratory epithelium into the rich blood capillary or neural network in the olfactory bulb. ${ }^{62,63}$ Translocation studies are challenging, especially in man, due to the small size and number of particles that will translocate, and the technical challenges in detecting carbon-based nanoparticles in biological tissue. However, recently, gold nanoparticles of a similar size to combustion derived nanoparticles have been shown to translocate rapidly from lungs into the circulation and accumulate in areas of vascular inflammation. ${ }^{33}$

\section{Mechanisms: autonomic dysfunction}

Inhaled particles, or the pulmonary inflammation caused by them, can stimulate neural sensory receptors on the alveolar surface which triggers changes in autonomic function leading to altered cardiovascular homeostasis. ${ }^{64}$ There is extensive evidence demonstrating reductions in various parameters of heart rate variability (HRV) after exposure to $\mathrm{PM}_{2.5 .}{ }^{65}$ Reduced $\mathrm{HRV}$ is a known marker of cardiac autonomic dysfunction, that has been linked to a worse prognosis in patients with heart disease and in the general population. ${ }^{66,67}$ Atrial fibrillation is a wellknown risk factor for stroke. Several animal studies have shown that exposure to urban PM and diesel exhaust particles increases the incidence or susceptibility to arrhythmia. ${ }^{68,69}$ This mechanism could contribute to the observed association between air pollution and cardioembolic strokes. ${ }^{70}$

Overall, a diverse range of pathophysiological mechanisms will contribute to the associations between air pollution and stroke (see Miller and Shah ${ }^{71} 2016$ for further discussion). As well as lending further weight to the case for causality between air pollution and stroke, elucidation of these mechanisms will offer important insight in identifying the most detrimental pollutions and susceptible populations.

\section{Possible interventions}

Air pollution represents a considerable burden to human health, yet currently the vast majority of countries do not meet 
accepted air quality standards. ${ }^{72}$ Nevertheless, the awareness of the health effects of air pollution has grown considerably over the last decade and the drive for interventions to tackle air pollution across the world should be a cause for optimism.

Measures to reduce air pollution will require policy changes at national, regional, and international levels. Burning of fossil fuels represents an important source of air pollution with wellrecognised health consequences. Moving away from the use of fossil fuels, towards cleaner and more renewable energy sources such as solar and wind power could mitigate not just the adverse health effects from air pollution, but also climate change as a result of greenhouse gases. The transportation sector clearly has a major role to play by developing integrated public transportation systems and regulating emission standards for motor vehicles. City planners should be incentivised to take air pollution into account and build residential areas away from polluting industries such as power plants or heavily congested roads. National early warning systems with realtime $\mathrm{PM}_{2.5}$ concentrations throughout the country could also help inform people, especially those likely to be a particular risk to air pollution (e.g., children, the elderly and those with preexisting cardiorespiratory disease) to avoid going outdoors during periods of poor air quality. In the case of rapidly industrialising LMICs, air pollution should not be seen as an inevitable side effect of modernisation. Through prudent leadership, air pollution can be decoupled from economic development using more sustainable models.

At an individual level, a number of simple measures could reduce personal exposure to air pollutants. Some of these measures include: commuting with public transport, cycling, or walking rather than using personal motor vehicles, limiting time spent outdoors during highly polluted periods, avoiding rush hour traffic or exercise near main traffic routes. Avoiding use of biomass fuel for domestic heating or cooking and improved domestic ventilation systems could have a large impact in LMICs. Individuals with pre-existing cardiorespiratory diseases, in particular, should be educated on the adverse cardiovascular risks posed by exposure to air pollution and advised to observe measures to reduce their exposure.

\section{Conclusions}

There is now substantial evidence linking air pollution and cardiovascular diseases including stroke. Epidemiological studies have demonstrated that both short- and long-term exposure to air pollution increases the risk of stroke. Controlled exposure studies in man and experimental studies have provided insight into the pathobiological mechanisms leading to the induction of endothelial dysfunction, atherosclerosis, platelet activation, and propensity for coagulation. Air pollution should be recognised more widely as one of the most important modifiable risk factors for the prevention and management of cardiovascular disease. Healthcare professionals will have an important role in promoting the awareness of this evidence, not just to improve the care of individual patients, but also to place pressure on policy makers for air pollution to be a public health priority.

\section{Disclosure}

The authors have no financial conflicts of interest.

\section{Acknowledgments}

This study was funded by British Heart Foundation Special Project Grant (SP/15/8/31575).

\section{References}

1. GBD 2015 Risk Factors Collaborators. Global, regional, and national comparative risk assessment of 79 behavioural, environmental and occupational, and metabolic risks or clusters of risks, 1990-2015: a systematic analysis for the Global Burden of Disease Study 2015. Lancet 2016;388:1659-1724.

2. Landrigan PJ, Fuller R, Acosta NJR, Adeyi O, Arnold R, Basu $N N$, et al. The Lancet Commission on pollution and health. Lancet. 2017 Oct 19 [Epub]. https://doi.org/10.1016/S01406736(17)32345-0.

3. Mustafic $H_{1}$ Jabre $P$, Caussin $C$, Murad MH, Escolano $S_{\text {, Tafflet }}$ $M$, et al. Main air pollutants and myocardial infarction: a systematic review and meta-analysis. JAMA 2012;307:713-721.

4. Shah AS, Langrish JP, Nair H, McAllister DA, Hunter AL, Donaldson $\mathrm{K}$, et al. Global association of air pollution and heart failure: a systematic review and meta-analysis. Lancet 2013;382:10391048.

5. Shah AS, Lee KK, McAllister DA, Hunter A, Nair H, Whiteley $W$, et al. Short term exposure to air pollution and stroke: systematic review and meta-analysis. BMJ 2015;350:h1295.

6. GBD 2015 Mortality and Causes of Death Collaborators. Global, regional, and national life expectancy, all-cause mortality, and cause-specific mortality for 249 causes of death, 1980-2015: a systematic analysis for the Global Burden of Disease Study 2015. Lancet 2016;388:1459-1544.

7. GBD 2015 Neurological Disorders Collaborator Group. Global, regional, and national burden of neurological disorders during 1990-2015: a systematic analysis for the Global Burden of Disease Study 2015. Lancet Neurol 2017;16:877-897. 
8. Nichols M, Townsend N, Scarborough P, Rayner M. Cardiovascular disease in Europe 2014: epidemiological update. Eur Heart J 2014;35:2950-2959.

9. Lelieveld J, Evans JS, Fnais M, Giannadaki D, Pozzer A. The contribution of outdoor air pollution sources to premature mortality on a global scale. Nature 2015;525:367-371.

10. Kim AS, Cahill E, Cheng NT. Global stroke belt: geographic variation in stroke burden worldwide. Stroke 2015;46:35643570.

11. Yadama GN, Katzman M, Yumkella KK, Mark MS. Fires, Fuel, and the Fate of 3 Billion: The State of the Energy Impoverished. Oxford, UK: Oxford University Press, 2013.

12. Bonjour $S$, Adair-Rohani $H$, Wolf J, Bruce NG, Mehta $S$, PrüssUstün $A$, et al. Solid fuel use for household cooking: country and regional estimates for 1980-2010. Environ Health Perspect 2013;121:784-790.

13. Cohen AJ, Brauer M, Burnett $R$, Anderson HR, Frostad J, Estep $K_{1}$ et al. Estimates and 25-year trends of the global burden of disease attributable to ambient air pollution: an analysis of data from the Global Burden of Diseases Study 2015. Lancet 2017;389:1907-1918.

14. GBD 2016 Risk Factors Collaborators. Global, regional, and national comparative risk assessment of 84 behavioural, environmental and occupational, and metabolic risks or clusters of risks, 1990-2016: a systematic analysis for the Global Burden of Disease Study 2016. Lancet 2017;390:1345-1422.

15. Eeftens M, Beelen R, de Hoogh $K$, Bellander T, Cesaroni G, Cirach $M_{1}$ et al. Development of Land Use Regression models for PM(2.5), PM(2.5) absorbance, PM(10) and PM(coarse) in 20 European study areas; results of the ESCAPE project. Environ Sci Technol 2012;46:11195-11205.

16. van Donkelaar A, Martin RV, Brauer M, Boys BL. Use of satellite observations for long-term exposure assessment of global concentrations of fine particulate matter. Environ Health Perspect 2015;123:135-143.

17. Nawrot TS, Perez L, Künzli N, Munters E, Nemery B. Public health importance of triggers of myocardial infarction: a comparative risk assessment. Lancet 2011;377:732-740.

18. Hoek G, Krishnan RM, Beelen R, Peters A, Ostro B, Brunekreef $B$, et al. Long-term air pollution exposure and cardio-respiratory mortality: a review. Environ Health 2013;12:43.

19. Faustini A, Rapp R, Forastiere F. Nitrogen dioxide and mortality: review and meta-analysis of long-term studies. Eur Respir J 2014;44:744-753.

20. Zhang P, Dong G, Sun B, Zhang L, Chen X, Ma N, et al. Longterm exposure to ambient air pollution and mortality due to cardiovascular disease and cerebrovascular disease in Shenyang, China. PLoS One 2011;6:e20827.
21. Stafoggia $M$, Cesaroni $G$, Peters $A$, Andersen ZJ, Badaloni $C$, Beelen $\mathrm{R}$, et al. Long-term exposure to ambient air pollution and incidence of cerebrovascular events: results from $11 \mathrm{Eu}$ ropean cohorts within the ESCAPE project. Environ Health Perspect 2014;122:919-925.

22. Miller KA, Siscovick DS, Sheppard L, Shepherd K, Sullivan JH,

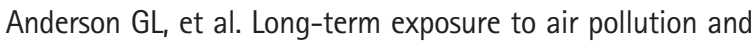
incidence of cardiovascular events in women. $N$ Engl J Med 2007;356:447-458.

23. Lipsett MJ, Ostro BD, Reynolds P, Goldberg D, Hertz A, Jerrett $M$, et al. Long-term exposure to air pollution and cardiorespiratory disease in the California teachers study cohort. Am J Respir Crit Care Med 2011;184:828-835.

24. Atkinson RW, Carey IM, Kent AJ, van Staa TP, Anderson HR, Cook DG. Long-term exposure to outdoor air pollution and incidence of cardiovascular diseases. Epidemiology 2013;24:4453.

25. Kloog I, Coull BA, Zanobetti A, Koutrakis P, Schwartz JD. Acute and chronic effects of particles on hospital admissions in New-England. PLoS One 2012;7:e34664.

26. Newman JD, Thurston GD, Cromar K, Guo Y, Rockman CB, Fisher EA, et al. Particulate air pollution and carotid artery stenosis. J Am Coll Cardiol 2015;65:1150-1151.

27. Knox EG. Meteorological associations of cerebrovascular disease mortality in England and Wales. J Epidemiol Community Health 1981;35:220-223.

28. Zhang ZF, Yu SZ, Zhou GD. Indoor air pollution of coal fumes as a risk factor of stroke, Shanghai. Am J Public Health 1988;78: 975-977.

29. Schwartz J. What are people dying of on high air pollution days? Environ Res 1994;64:26-35.

30. Dominici F, Peng RD, Bell ML, Pham L, McDermott A, Zeger SL, et al. Fine particulate air pollution and hospital admission for cardiovascular and respiratory diseases. JAMA 2006;295:11271134.

31. Leiva $G M A$, Santibañez DA, Ibarra $E S$, Matus $C P$, Seguel R. A five-year study of particulate matter (PM2.5) and cerebrovascular diseases. Environ Pollut 2013;181:1-6.

32. Villeneuve PJ, Johnson JY, Pasichnyk D, Lowes J, Kirkland S, Rowe BH. Short-term effects of ambient air pollution on stroke: who is most vulnerable? Sci Total Environ 2012;430:193-201.

33. Miller MR, Raftis JB, Langrish JP, McLean SG, Samutrtai $P$, Connell SP, et al. Inhaled nanoparticles accumulate at sites of vascular disease. ACS Nano 2017;11:4542-4552.

34. Mills NL, Donaldson K, Hadoke PW, Boon NA, MacNee W, Cassee FR, et al. Adverse cardiovascular effects of air pollution. Nat Clin Pract Cardiovasc Med 2009;6:36-44.

35. Guo L, Li B, Miao JJ, Yun Y, Li GK, Sang N. Seasonal variation in 
air particulate matter (PM10) exposure-induced ischemia-like injuries in the rat brain. Chem Res Toxicol 2015;28:431-439.

36. Davis DA, Akopian G, Walsh JP, Sioutas C, Morgan TE, Finch CE. Urban air pollutants reduce synaptic function of CA1 neurons via an NMDA/NO pathway in vitro. $J$ Neurochem 2013;127:509-519.

37. Morgan TE, Davis DA, Iwata N, Tanner JA, Snyder D, Ning $Z$, et al. Glutamatergic neurons in rodent models respond to nanoscale particulate urban air pollutants in vivo and in vitro. Environ Health Perspect 2011;119:1003-1009.

38. Wallenborn JG, Schladweiler MC, Nyska A, Johnson JA, Thomas $\mathrm{R}$, Jaskot RH, et al. Cardiopulmonary responses of Wistar Kyoto, spontaneously hypertensive, and stroke-prone spontaneously hypertensive rats to particulate matter (PM) exposure. J Toxicol Environ Health A 2007;70:1912-1922.

39. Fujimaki $H$, Kurokawa $Y$, Yamamoto $S$, Satoh M. Distinct requirements for interleukin-6 in airway inflammation induced by diesel exhaust in mice. Immunopharmacol Immunotoxicol 2006;28:703-714.

40. Oppenheim HA, Lucero J, Guyot AC, Herbert LM, McDonald $J D$, Mabondzo A, et al. Exposure to vehicle emissions results in altered blood brain barrier permeability and expression of matrix metalloproteinases and tight junction proteins in mice. Part Fibre Toxicol 2013;10:62.

41. Lucking AJ, Lundback M, Mills NL, Faratian D, Barath SL, Pourazar J, et al. Diesel exhaust inhalation increases thrombus formation in man. Eur Heart $J$ 2008;29:3043-3051.

42. Mills NL, Törnqvist $H$, Gonzalez MC, Vink E, Robinson SD, Söderberg $S$, et al. Ischemic and thrombotic effects of dilute diesel-exhaust inhalation in men with coronary heart disease. N Engl J Med 2007;357:1075-1082.

43. Pope CA 3rd, Bhatnagar A, McCracken JP, Abplanalp W, Conklin DJ, O'Toole T. Exposure to fine particulate air pollution is associated with endothelial injury and systemic inflammation. Circ Res 2016;119:1204-1214.

44. O'Toole TE, Hellmann J, Wheat L, Haberzettl P, Lee J, Conklin DJ, et al. Episodic exposure to fine particulate air pollution decreases circulating levels of endothelial progenitor cells. Circ Res 2010;107:200-203.

45. Wellenius GA, Boyle LD, Wilker EH, Sorond FA, Coull BA, Koutrakis $\mathrm{P}$, et al. Ambient fine particulate matter alters cerebral hemodynamics in the elderly. Stroke 2013;44:15321536.

46. Miller MR. The role of oxidative stress in the cardiovascular actions of particulate air pollution. Biochem Soc Trans 2014;42: 1006-1011.

47. Miller MR, Shaw CA, Langrish JP. From particles to patients: oxidative stress and the cardiovascular effects of air pollu- tion. Future Cardiol 2012;8:577-602.

48. Seaton A, MacNee W, Donaldson K, Godden D. Particulate air pollution and acute health effects. Lancet 1995;345:176-178.

49. Tsai DH, Amyai N, Marques-Vidal P, Wang JL, Riediker M, Mooser $V$, et al. Effects of particulate matter on inflammatory markers in the general adult population. Part Fibre Toxicol 2012;9:24.

50. Ghio AJ, Kim C, Devlin RB. Concentrated ambient air particles induce mild pulmonary inflammation in healthy human volunteers. Am J Respir Crit Care Med 2000;162(3 Pt 1):981988.

51. Hoffmann B, Moebus S, Dragano N, Stang A, Möhlenkamp S, Schmermund $A$, et al. Chronic residential exposure to particulate matter air pollution and systemic inflammatory markers. Environ Health Perspect 2009;117:1302-1308.

52. Mills NL, Törnqvist $H$, Robinson SD, Gonzalez M, Darnley $K_{\text {, }}$ MacNee $W$, et al. Diesel exhaust inhalation causes vascular dysfunction and impaired endogenous fibrinolysis. Circulation 2005;112:3930-3936.

53. Gong KW, Zhao W, Li N, Barajas B, Kleinman M, Sioutas C, et al. Air-pollutant chemicals and oxidized lipids exhibit genome-wide synergistic effects on endothelial cells. Genome Biol 2007;8:R149.

54. Brüske I, Hampel R, Baumgärtner Z, Rückerl R, Greven S, Koenig $W$, et al. Ambient air pollution and lipoprotein-associated phospholipase $A(2)$ in survivors of myocardial infarction. Environ Health Perspect 2011;119:921-926.

55. Oberdörster G, Sharp Z, Atudorei V, Elder A, Gelein R, Lunts $A$, et al. Extrapulmonary translocation of ultrafine carbon particles following whole-body inhalation exposure of rats. $J$ Toxicol Environ Health A 2002;65:1531-1543.

56. Aung HH, Lame MW, Gohil K, He G, Denison MS, Rutledge $J C$, et al. Comparative gene responses to collected ambient particles in vitro: endothelial responses. Physiol Genomics 2011;43:917-929.

57. Lee CC, Huang SH, Yang YT, Cheng YW, Li CH, Kang JJ. Motorcycle exhaust particles up-regulate expression of vascular adhesion molecule-1 and intercellular adhesion molecule-1 in human umbilical vein endothelial cells. Toxicol In Vitro 2012;26:552-560.

58. Montiel-Dávalos A, Alfaro-Moreno E, López-Marure R. PM2.5 and PM10 induce the expression of adhesion molecules and the adhesion of monocytic cells to human umbilical vein endothelial cells. Inhal Toxicol 2007;19 Suppl 1:91-98.

59. Sumanasekera WK, Ivanova MM, Johnston BJ, Dougherty SM, Sumanasekera GU, Myers SR, et al. Rapid effects of diesel exhaust particulate extracts on intracellular signaling in human endothelial cells. Toxicol Lett 2007;174:61-73. 
60. Chao MW, Kozlosky J, Po IP, Strickland PO, Svoboda KK, Cooper $\mathrm{K}$, et al. Diesel exhaust particle exposure causes redistribution of endothelial tube VE-cadherin. Toxicology2011;279:73-84.

61. Li R, Ning Z, Cui J, Yu F, Sioutas C, Hsiai T. Diesel exhaust particles modulate vascular endothelial cell permeability: implication of Z0-1 expression. Toxicol Lett 2010;197:163-168.

62. Balasubramanian SK, Poh KW, Ong CN, Kreyling WG, Ong WY, Yu LE. The effect of primary particle size on biodistribution of inhaled gold nano-agglomerates. Biomaterials 2013;34:5439-5452.

63. Hopkins LE, Laing EA, Peake JL, Uyeminami D, Mack SM, Li X, et al. Repeated iron-soot exposure and nose-to-brain transport of inhaled ultrafine particles. Toxicol Pathol. 2017 Jan 1 [Epub]. https://doi.org/10.1177/0192623317729222.

64. Pope CA 3rd, Verrier RL, Lovett EG, Larson AC, Raizenne $M E_{1}$

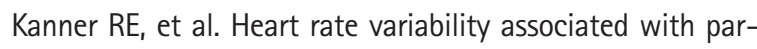
ticulate air pollution. Am Heart J 1999;138(5 Pt 1):890-899.

65. Pieters $N$, Plusquin $M, \operatorname{Cox} B$, Kicinski $M$, Vangronsveld J, Nawrot TS. An epidemiological appraisal of the association between heart rate variability and particulate air pollution: a meta-analysis. Heart 2012;98:1127-1135.

66. Tsuji H, Larson MG, Venditti FJ Jr, Manders ES, Evans JC,

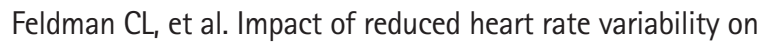
risk for cardiac events. The Framingham Heart Study. Circu- lation 1996;94:2850-2855.

67. La Rovere MT, Pinna GD, Maestri R, Mortara A, Capomolla S, Febo 0 , et al. Short-term heart rate variability strongly predicts sudden cardiac death in chronic heart failure patients. Circulation 2003;107:565-570.

68. Wang T, Lang GD, Moreno-Vinasco L, Huang Y, Goonewardena SN, Peng YJ, et al. Particulate matter induces cardiac arrhythmias via dysregulation of carotid body sensitivity and cardiac sodium channels. Am J Respir Cell Mol Biol 2012;46:524-531.

69. Nadziejko C, Fang K, Narciso S, Zhong M, Su WC, Gordon T, et al. Effect of particulate and gaseous pollutants on spontaneous arrhythmias in aged rats. Inhal Toxicol 2004;16:373380.

70. Chung JW, Bang OY, Ahn K, Park SS, Park TH, Kim JG, et al. Air pollution is associated with ischemic stroke via cardiogenic embolism. Stroke 2017;48:17-23.

71. Miller MR, Shah AS. Ambient particles and cerebrovascular disease. In: Bondy SC, Campbell A. Inflammation, Aging, and Oxidative Stress. Cham, CH: Springer, 2016:133-160.

72. World Health Organization. WHO Global Urban Ambient Air Pollution Database (update 2016). http://www.who.int/phe/ health_topics/outdoorair/databases/cities/en/. 2016. Accessed January 19, 2018. 